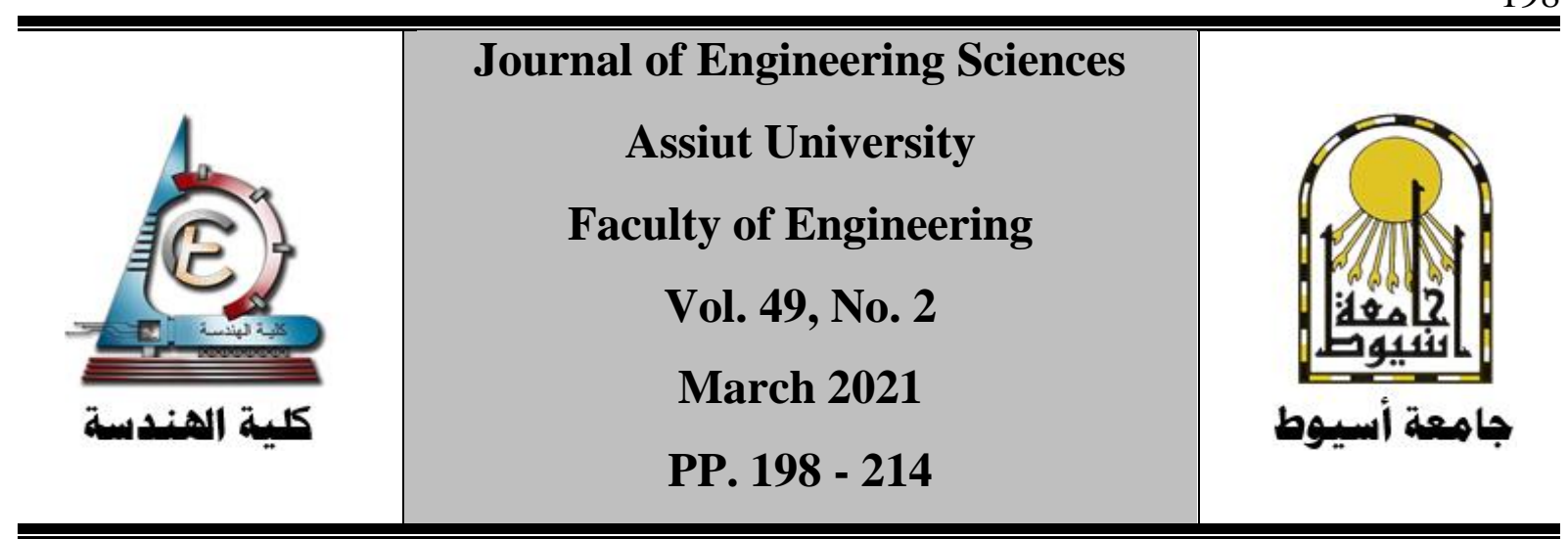

\title{
EXPERIMENTAL STUDY ON COMPRESSIVE STRENGTH AND FLEXURAL RIGIDITY OF EPOXY GRANITE COMPOSITE MATERIAL
}

\section{Mohamed Omar' ${ }^{1}$ Yasser Abdelrhman², Ibrahim M. Hassab-Allah², Wael M. Khierldeen ${ }^{2,3}$}

\footnotetext{
${ }^{1}$ Integrated Technical Education Cluster, Assiut, Egypt. Email: M.Rizk2290@ gmail.com

${ }^{2}$ Mechanical Engineering Department, Faculty of Engineering, Assiut university 71516, Egypt.

${ }^{3}$ Industrial and Manufacturing Engineering Department, Egypt-Japan University of Science and Technology 21568, Egypt
}

\begin{abstract}
In Egypt, large quantities of coarse granite wastes are produced annually during the quarrying operations of granite rocks. This waste represents a potentially useful source of material for a variety of applications such as a filler material in epoxy granite composite material. In this work a new eco-friendly composite material studied as a substitute for machine tools traditional materials, like cast iron, to produce better efficiency with lower cost. This study aims to investigate the mechanical properties of granite epoxy composite by using the local epoxy (kemapoxy 150) and the granite residues in the Egyptian quarries. The investigated processing variable was epoxy content, and the mechanical characterization ware carried out by compressive and flexural tests according to the ASTM standard method B. Commercially available, Aswan red granite was procured, crushed, and sieved to three size ranges from 0.150 to $8 \mathrm{~mm}$, respectively. Epoxy ratios of $80: 20,85: 15$ have been used with granite aggregate size mix with small, medium, and coarse size proportions of 50:25:25 respectively for preparing the specimens with granite granular size range $(0.150-8) \mathrm{mm}$. The results show that Epoxy granite composite with granite to epoxy ratio of 80:20\% wt. induced the highest compressive strength (72.15 MPa) while the composite with the ratio of 85:15\% wt. induced the highest flexural strength $(20.1 \mathrm{MPa})$. Epoxy granite composite show superior results with respect to cement concrete, polyester concrete, and natural granite.
\end{abstract}

Keywords: Epoxy-Granite; Composite materials; Compressive strength; Flexural rigidity; Resin ratio 


\section{Introduction}

Eco-friendly, high strength, low weight, low cost, Recyclability, and durability are essential considerations in the choice of modern products. recently composite materials with their inimitable, feature-rich properties have become a trend in the industrial trend to maximize materials usage and economics of industrial production process and production techniques. In this respect, the focus on the technical development of highly competitive constructional composite materials needs to be continuously sharpened. Another important cause for this trend is the usage of composite materials like epoxy granite composite would result in economic optimization of granite industry wastes, which are produced in large quantities in quarries. The convenient use of granite wastes will render them as useful profitable products. Pollution will be reduced and natural resources will be conserved [1]. Granite reinforces Epoxy composite is the material produced using high strength coarse and fine granite powder generated as a waste from quarrying and mining granite rocks[1] as a filler material. The major desired factor which affected on structure and material of machine tools' properties are high structural stiffness, excellent damping, and low thermal sensitivity[2]. Therefore, the produced material is expected to be ideal to develop alternative materials for machine tools structures with excellent flexible operation performance[3],[4]High productivity, and low cost [5]-. Table 1.

Table 1. Comparison of the properties of steel, cast iron, and polymer concrete [5]

\begin{tabular}{|l|c|c|c|c|}
\hline Properties & Units & Steel & $\begin{array}{c}\text { Grey cast } \\
\text { iron }\end{array}$ & $\begin{array}{c}\text { Polymer } \\
\text { concrete }\end{array}$ \\
\hline Density & $\mathrm{g} / \mathrm{cm}^{3}$ & 7.85 & 7.2 & $2.1-2.4$ \\
\hline Compressive strength & $\mathrm{N} / \mathrm{mm}^{2}$ & $250-1200$ & $350-450$ & $140-170$ \\
\hline Bending strength & $\mathrm{N} / \mathrm{mm}^{2}$ & $400-1600$ & $150-400$ & $25-40$ \\
\hline Young's modulus & $\mathrm{KN} / \mathrm{mm}^{2}$ & 210 & $80-120$ & $30-40$ \\
\hline Heat-transfer coefficient & $\mathrm{W} /\left(\mathrm{m}^{*} \mathrm{~K}\right)$ & 50 & 50 & $1 .-20$ \\
\hline Thermal expansion coefficient & $\mu \mathrm{m} /\left(\mathrm{m}^{*} \mathrm{~K}\right)$ & 12 & 10 & $12-20$ \\
\hline Specific heat & $\mathrm{kJ} /\left(\mathrm{kg}^{*} \mathrm{~K}\right)$ & $0.45-0.5$ & 0.5 & $0.9-1.3$ \\
\hline Logarithmic decrement & & 0.002 & 0.003 & $0.02-0.03$ \\
\hline Cost & & 7.67 & 5.11 & 2.56 \\
\hline Manufacturing energy demand & $\mathrm{MJ} / \mathrm{dm}^{3}$ & 160 & 120 & 25 \\
\hline
\end{tabular}

Tsung-Chia Chen et al. [6] verified the effectiveness and the feasibility of the fabrication of the machine tools structure like milling machines using epoxy granite composite and show improvements in the manufacturing process. Parbhu Raja et al. [7] investigated that replacing the cast-iron base of a vertical machining center with an epoxy granite composite base and find an improvement in the machine products' quality and productivity. Shanmugam et al. [8] use epoxy-granite composite made of large granite aggregates as a filler material in the machine 
tools and prove it as an acceptable and reliable solution for machine tools structures. Antonio Piratteli et al. [9] investigated the effectiveness of using the epoxy content ratio of 15 and $20 \%$ wt. and granite aggregates rate of (50\% large and 50\% small ) on the compression strength of epoxy granite composite. The results indicate a significantly higher magnitude of compression strength relative to comparable commercial brands of machine tools made from traditional materials [9]. Subhash et al. [10] investigated the effectiveness of using granite powder as a reinforcement material at epoxy granite composite in the weight, strength, and surface finish. they found that epoxy granite composite with resin ratio between $60 \%$ to $70 \%$ is the most suitable composite for structural and engineering applications like machine tools structure. Maria Luiza et al. [11] showed that epoxy granite composite had satisfactory physical and mechanical properties, like resistance to temperature oscillations, and high resistance to wear and impact. Selvakumar et al. [12] carried out numerical, analytical, and experimental studies on specimens of steel, cast iron, and epoxy granite at constant stiffness to compare the properties of structures from these materials more precisely. They observed that, at the same stiffness, epoxy granite composites offer high damping performance with significant weight reduction, as induced vibrations were dampening out at a faster rate in case of epoxy granite composite compared to cast iron and steel specimens. Balakrishna et al. [13] investigated the mechanical properties such as compressive, flexural, and tensile strength and the vibration behavior of epoxy granite composites with and without using additional particles of cast iron as filler materials. It was found that the cast iron particulates percentage affects damping and mechanical properties of the produced composite. they found that compressive strength increases with the increase in the reinforcement cast iron particulates, while damping, tensile and flexural strength decrease with increasing the cast iron reinforce particulates [13]. Deepak et al. [14] investigated the mechanical properties of epoxy granite composite such as compressive and flexural strength, damping properties, and modulus of elasticity. The results showed that the density of epoxy granite composite three times lower than the density of cast iron with better vibration damping performance and less manufacturing time. P.Mani et al. [15] presented a comparative analysis study on epoxy concretes, polyester concrete, and conventional cement concrete composites with the same aggregate in each composite They studied Mechanical properties such as compressive, flexural, tensile, and impact strength and found that both epoxy and polyester concrete show properties far superior to conventional concrete while epoxy concrete showed superior properties to polyester concrete. In this study an investigation of the compressive and flexural properties of epoxy granite composite material according to ASTM-579-01 and ASTM-C580 standard were preformed using Egyptian granite as a reinforced material, local epoxy (kemapoxy 150) as a matrix material to produce epoxy granite composite material for the industrial application. Granite to the epoxy ratio of 80:20 and $85: 15 \%$ wt. with granite granular size range $(0.150-8) \mathrm{mm}$ were selected in this study.

\section{Experimental Details}

\subsection{Materials}

In this work a mixture of course and fine granite particles were used as a reinforcement. Crushed granite is an intrusive volcanic rock (igneous rocks) that consists mainly of orthoclase, quartz, and mica with coarse crystalline grains [16]. Granite rubble is considered to be a non-reactive aggregate, however, depending on the quarry, granite may have various impurities including harmful minerals containing active $\mathrm{SiO}_{2}$ [17]. The used coarse and fine granite powder was brought from the Aswan area in southern Egypt, which generated from quarrying and mining granite rock. The chemical composition of the used granite is shown in table 2 . 
Table 2: XRF Commercial analysis of the used granite [18].

\begin{tabular}{|c|c|c|c|}
\hline Element & ms\% & mol\% & Sigma \\
\hline $\mathbf{A l}$ & 8.5000 & 10.8068 & 3.7957 \\
\hline $\mathbf{S i}$ & 47.6969 & 58.2576 & 4.1407 \\
\hline $\mathbf{k}$ & 11.2912 & 9.9059 & 3.4859 \\
\hline $\mathbf{C a}$ & 3.5633 & 3.0498 & 2.9038 \\
\hline $\mathbf{T i}$ & 1.9455 & 1.3933 & 1.4508 \\
\hline $\mathbf{M n}$ & 1.1757 & 0.7342 & 1.0394 \\
\hline $\mathbf{F e}$ & 25.6899 & 15.7803 & 1.0007 \\
\hline $\mathbf{Z n}$ & 0.1375 & 0.0722 & 1.2422 \\
\hline
\end{tabular}

Commercial diglycidyl ether of bisphenol A (DGEBA) (kemapoxy 150)[19], which has been supplied by chemicals for modern building international (CMB) Co., Egypt, with epoxide equivalence weight in the range of $182-196$ g/equiv. and density at $25^{\circ} \mathrm{C}\left(1.11 \mathrm{~g} / \mathrm{cm}^{3}\right)$ which able to act as a lubricant in its liquid phase. With two components, solvent-free and nonpigmented liquid epoxy were used as a matrix material. It is utilized as a coating where outstanding mechanical stresses and chemical resistance are required. It complies with ASTM C 881 \& ES 1382[20]. The diglycidyl ether of bisphenol-A (DGEBA) is produced by reacting bisphenol-A with epichlorohydrin in the presence of a basic catalyst [21], [22].

\subsection{Samples Preparation}

Granite waste and fine powder granite which are generated from quarrying and mining granite rocks collected, crushed, and sieved in mineral processing laboratories, in the Mining and Metallurgical Engineering Department, Faculty of Engineering, Assiut University. Stone Jaw Crusher has been used for crushing granite slabs into aggregates less than or equal to $8 \mathrm{~mm}$. Roll Crusher was used for crushing granite aggregates into small aggregates and Disk Mill for grinding the small aggregates to get fine granite aggregates. Granite aggregates are sieved after each crushing step. Granite aggregates are categorized into three groups as 0.150 -to 1 -mm fine grain,1-to 5-mm middle grain, and 5-to $-8 \mathrm{~mm}$ coarse grain. The amount of the granite aggregates ratio is given in Table 3. 
Mohamed Omar et al., Experimental Study on Compressive Strength and Flexural Rigidity ...

Table 3: Aggregate Size Mix

\begin{tabular}{|l|l|l|l|}
\hline Aggregate Size & Fine (0.150-1) mm & Middle (1-5) mm & Coarse (5-8) mm \\
\hline weight percentage & $50 \mathrm{Wt} \%$ & $25 \mathrm{Wt} \%$ & $25 \mathrm{Wt} \%$ \\
\hline
\end{tabular}

Granite granules were washed well with water to get rid of dust and residues. Then the granite was dried from the water residual. Acrylic molds were prepared according to standard ASTM579-01 and ASTM-C580, molds sprayed from the inside using a release agent for easy removal of the specimens. Component B (hardener) added to component A (resin) and mixed using a mixer for 3 minutes in the ratio of (2A to 1B) with mixer velocity of 300 r.p.m. [19] after that the filling material of the granite aggregates added to the mixture of epoxy and mixed again for 15 minutes to make sure of getting a homogeneous mixture of the epoxy granite composite. Granite aggregates were mixed with epoxy in two ratios of $(85: 20) \%$ and (80:20) \% by weight. Acrylic mold has been used for casting the specimens as shown in Fig. 1.

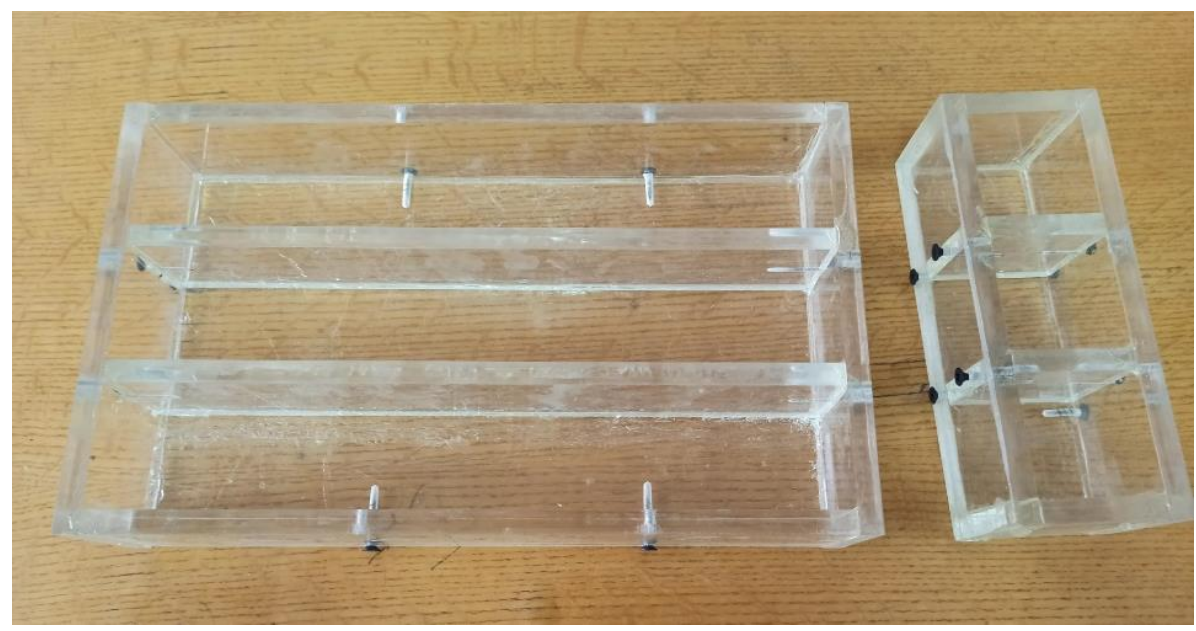

Fig. 1. Acrylic mold for compassion, flexural, and damping spearmints tests

Fill the mold one-half full with epoxy granite[23], [24], shake the molds using vibration table for 10 minutes to remove entrapped air then fill the remainder of the mold and shake the mold again for another 10 minutes. Then, the composite was cured for 24 hours at room temperature. The produced specimen was then aged for seven days before testing to ensure that the composite is completely hardened [19]. Each sample has been labeled with specimen type and number.

The appropriate weight ratio of epoxy resin for preparing the epoxy granite composite with the selected granite granular size is determined according to the following equations to determine the minimum resin content (MRC\%) [11].

$$
\operatorname{MRC} \%=\left(\frac{V V \% X \rho_{\text {risen }}}{V V \% X \rho_{\text {risen }}+(100-V V \%) X \rho_{\text {granite }}}\right) \times 100
$$

Where: The density of the granite used was $2.61 \mathrm{~g} / \mathrm{cm}^{3}$ and the density of the used granite (kemapoxy 150) was $1.11 \mathrm{~g} / \mathrm{cm}^{3}$, and, 


$$
\mathrm{VV} \%=\left(1-\frac{\text { dray apperent denisty of particals }}{\text { apperant denisty of granite }}\right) \times 100
$$

Where: Dray apparent density of partials was $1.915 \mathrm{~g} / \mathrm{cm}^{3}$, the density of granite was $2.61 \mathrm{~g} / \mathrm{cm}^{3}$

The value for the minimum resin content was found to be $13.37 \%$, which represents the minimum percentage of the weight of resin needed to fill the void volume. However, in this study, $15 \%$ and $20 \%$ of resin were used in the formulation of epoxy granite composite as a margin of safety to obtain a cohesive composite of epoxy and granite. The granite epoxy composite manufactured specimens used in the conducted compression and flexural test acceding to ASTM standards are shown in Fig. 2.

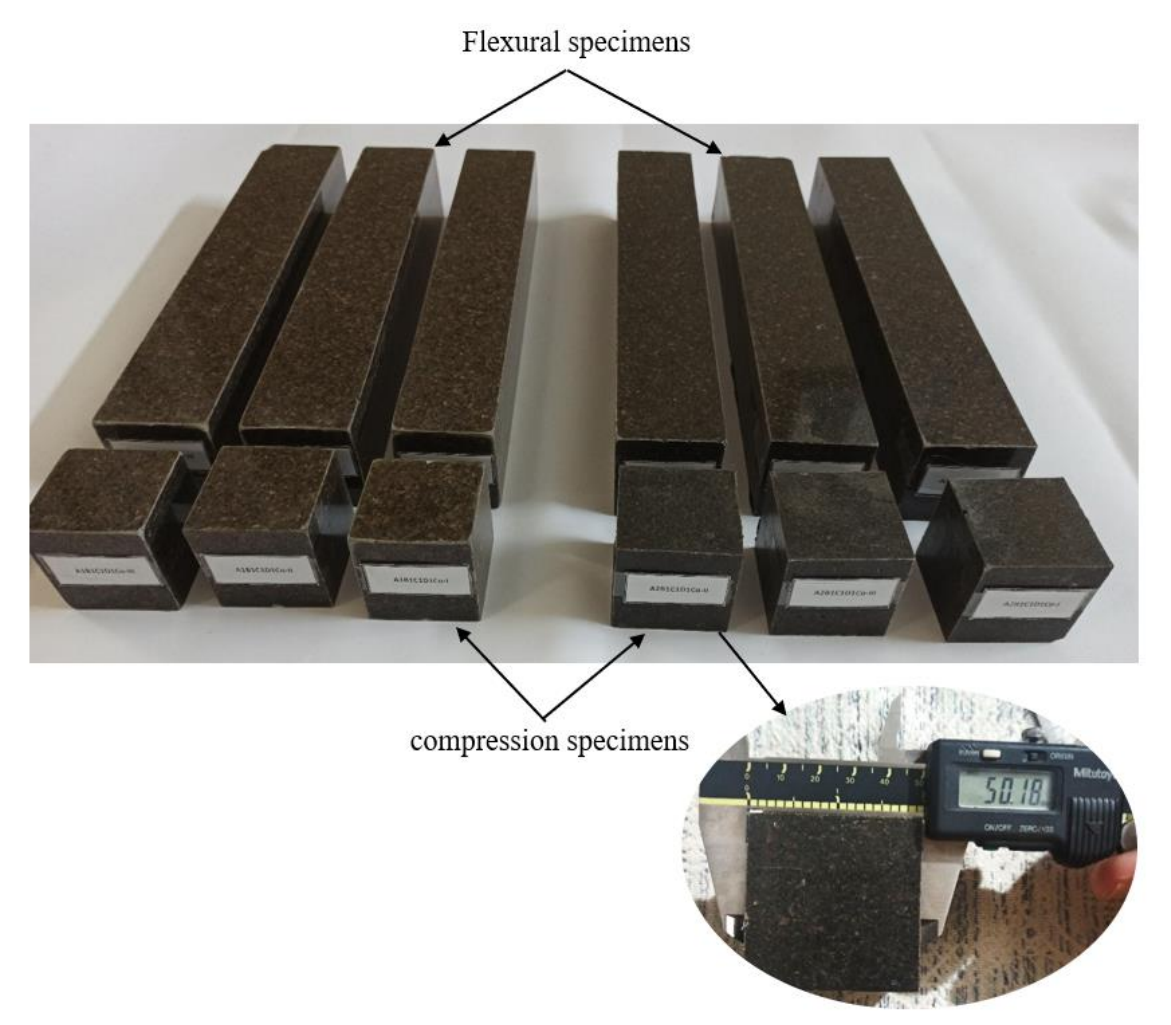

Fig. 2. Compression cubic and flexural beam test specimens of epoxy granite composed.

\subsection{Compression test}

The tests were conducted according to ASTM-579-01 Method B with the universal testing machine to determine the compressive strength of the epoxy granite composite.

Compressive test specimens were prepared, as cubes with the dimension of $\left(50_{-3.0}^{+1.5}\right) \mathrm{mm}$ with a flat and smooth face as shown in Fig. 3., each faces normal to each other and the angle between each face within the limit of $\left(90 \pm 0.5^{\circ}\right)$ and the tests was carried out using a universal testing machine $\mathrm{M} / \mathrm{C}$ in Force and Material Metrology Laboratory, National Institute of Standards (NIS), Ministry of Higher Education and Scientific Research, Haram - Giza -Egypt. 


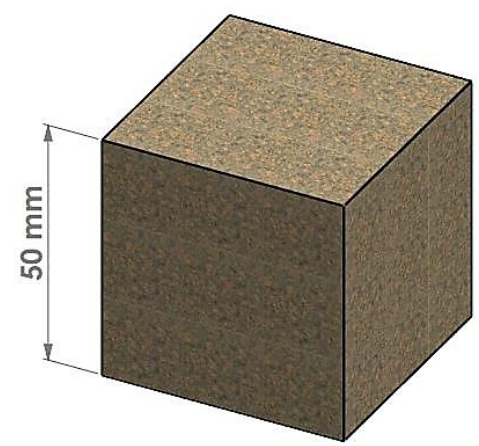

Fig. 3. The compressive strength test specimen

A Spherical bearing block with a diameter of more than three-time of the specimen width was used. the test set-up as shown in Fig. 4. The load applied continuously at the rate of (41 MPa/ min) and without shock, epoxy granite specimen loaded till failure and compressive strength calculated according to the following formula [23]:

$$
\mathrm{S}=(\mathrm{W}) /\left(\mathrm{L}_{1} \mathrm{X} \mathrm{L} \mathrm{L}_{2}\right)
$$

Where: $\mathrm{S}$ is the Compressive strength in $(\mathrm{MPa}), \mathrm{W}$ is the Maximum load in $(\mathrm{N}), \mathrm{L}_{1}$ and $\mathrm{L}_{2}$ are the cross-section dimensions of prism measured using micrometer with the accuracy of \pm 0.02 $\mathrm{mm}$.

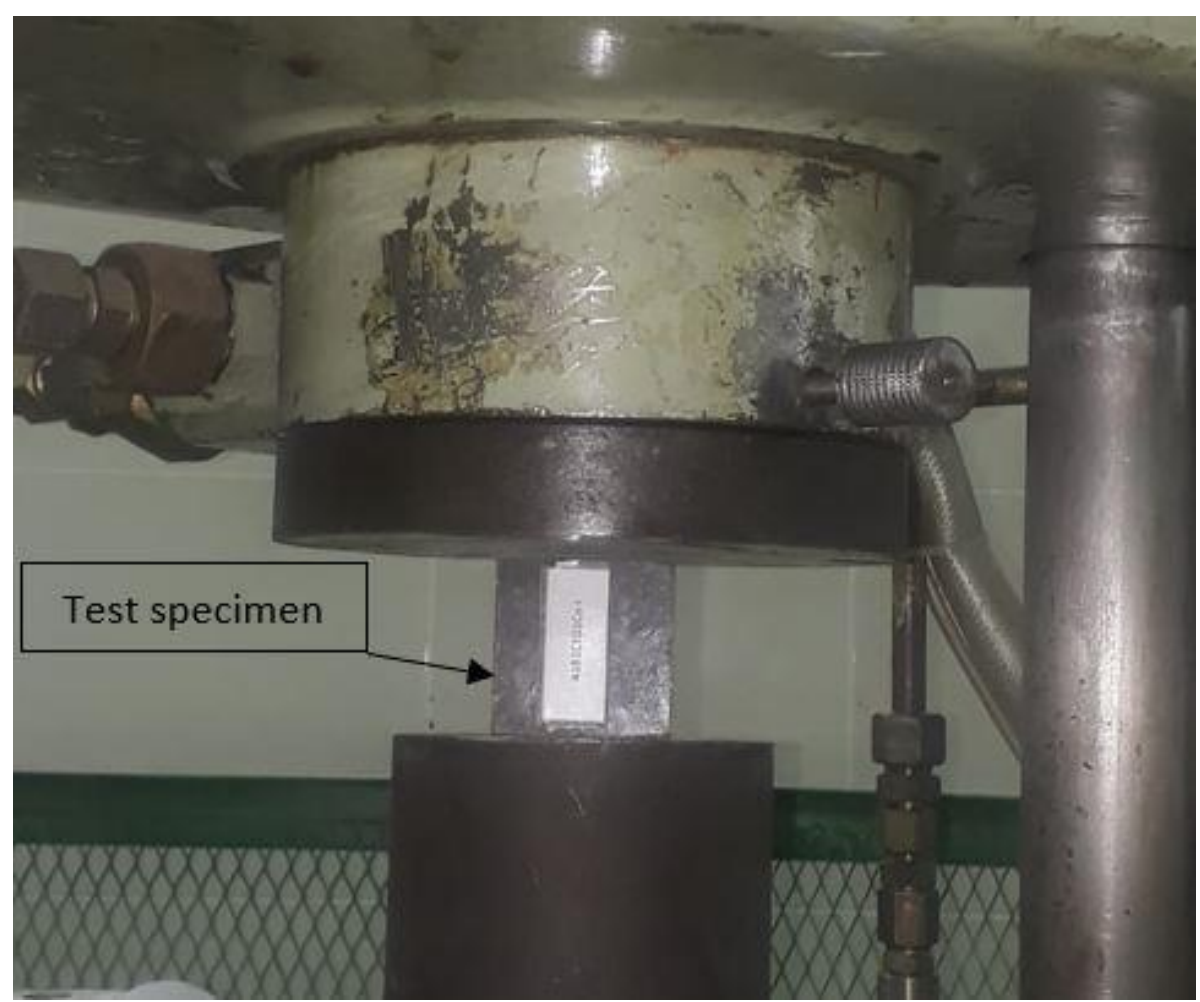

Fig. 4. Compressive test set-up 


\subsection{Flexural test}

The tests were conducted according to ASTM-C580 Method B [24] and a universal testing machine $\mathrm{M} / \mathrm{C}$ in Force and Material Metrology Laboratory, National Institute of Standards (NIS), Ministry of Higher Education and Scientific Research, Haram - Giza - Egypt. Testing machine was used to determine the flexural strength of the polymer composite of epoxy granite composite in the shape of a molded beam with rectangular cross-section area as shown in Fig. 5 .

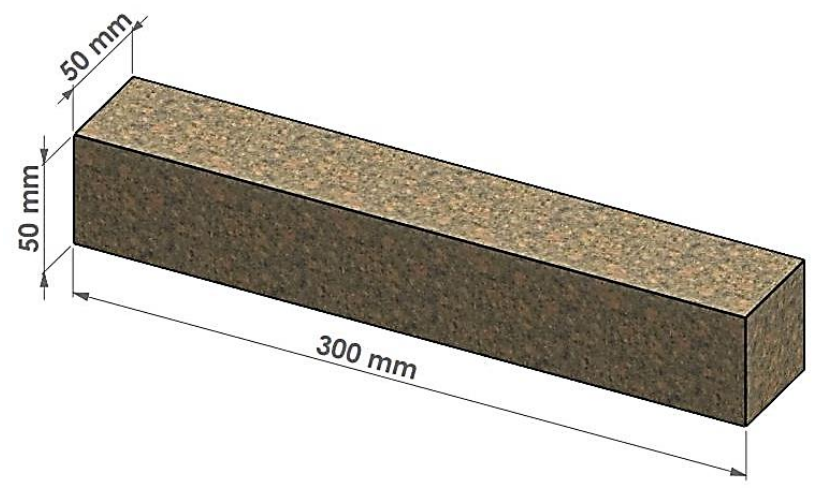

Fig. 5. Flexural strength test specimen

Flexural strength was applied using a rectangular cross-section bar of epoxy granite composite using the three-point bending method. The radius of the Loading nose is $6.35 \mathrm{~mm}$ as shown in Fig.6.

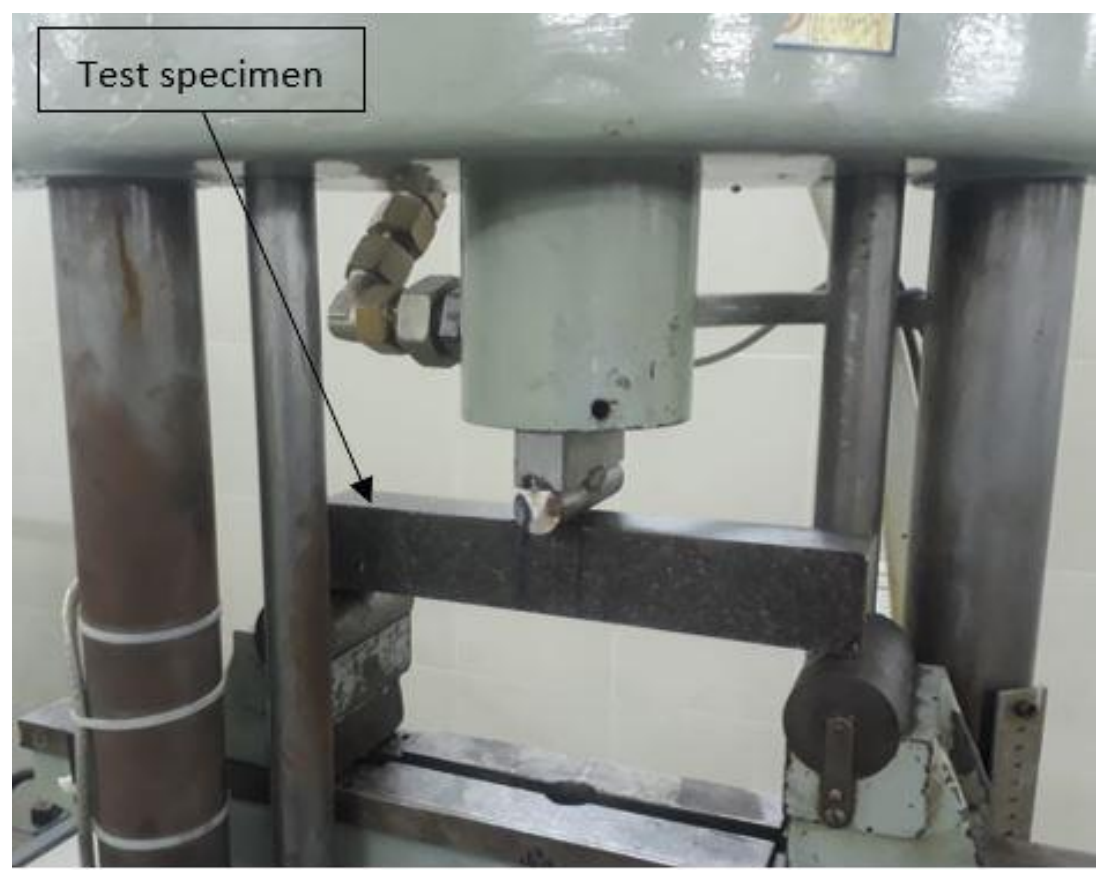

Fig. 6. Flexural test set-up

A crosshead speed of the universal testing machine is determined by using the following formula to achieve a strain rate $(0.01 \pm 0.001)$ per minute at the bottom and top of the testing beams [24]. 


$$
\text { Speed }=\frac{0.00167 \times L^{2}}{d}
$$

Where: Speed is the cross speed of the head $(\mathrm{mm} / \mathrm{min}), \mathrm{L}$ is the span in $(\mathrm{mm}), \mathrm{d}=$ depth of tested granite epoxy beam in $(\mathrm{mm})$. The used crosshead speed was $2.15 \mathrm{~mm} / \mathrm{min}$.

Epoxy granite specimens with the dimension of (50 \pm 3 ) mm square section by (300) mm length was prepared according to ASTM-C580/Method (B). The flexural strength and young modulus are calculated by using the following formula.[24], [18].

$$
\begin{gathered}
S=\frac{3 F L}{2 b d^{2}} \\
E=\frac{L^{3} F}{4 b d^{3} \delta}
\end{gathered}
$$

Where: $\mathrm{S}=$ stress in the specimen at midspan, psi $(\mathrm{MPa}), \mathrm{F}=$ the maximum load at or before the moment of crack or break. $(\mathrm{N}), \mathrm{L}=$ span, in. $(\mathrm{mm}), \mathrm{b}=$ width of beam tested, in. $(\mathrm{mm}), \mathrm{d}=$ depth of beam tested, in. $(\mathrm{mm})$. and $\delta$ is maximum beam deflection. Three samples of granite epoxy composite were tested, and the average results values were recorded.

\section{Results and Discussions}

The results of the compressive strength and the flexural strength of the produce epoxy granite composite specimens with different percentage ratios of the epoxy are shown in Table 4. Compressive strength values and flexural strength for each granite epoxy specimen are checked to be sure that no specimen value differs from the observed mean value by more than $15 \%$ [23]. The mean values observed of the compressive strength were $72.15 \mathrm{MPa}$ for granite to the epoxy ratio of (80:20) \% wt and $61.33 \mathrm{MPa}$ for granite to the epoxy ratio of $(85: 15) \% \mathrm{wt}$, the mean values observed of the flexural strength were $19.79 \mathrm{MPa}$ for granite to epoxy ratio of (80:20) \% wt. and $21.18 \mathrm{MPa}$ for granite to epoxy ratio of $(85: 15) \% \mathrm{wt}$. It found that granite granule size provides greater ductility and the use of epoxy resin with strong adhesive properties ensures high strength and decreased deformation due to creep [25].

Table 4. Results of compressive and flexural strength results of specimens and Standard deviation.

\begin{tabular}{|c|c|c|c|}
\hline Granite to epoxy ratio & Sample NO. & Compressive strength & Flexural strength \\
\hline \multirow{3}{*}{$\mathbf{8 5 : 1 5} \%$} & 1 & 59 & 21.69 \\
\cline { 2 - 4 } & 2 & 62 & 21.40 \\
\cline { 2 - 4 } & 3 & 63 & 20.46 \\
\hline \multirow{2}{*}{$\mathbf{8 0 : 2 0 \%}$} & 1 & 70.98 & 20.5 \\
\cline { 2 - 4 } & 2 & 71.98 & 20.45 \\
\cline { 2 - 4 } & 3 & 73.5 & 18.41 \\
\hline
\end{tabular}


Table 5. compressive, flexural strength and Flexural modulus.

\begin{tabular}{|c|c|c|c|}
\hline Epoxy ratio & Compressive strength & Flexural strength & $\begin{array}{c}\text { Flexural modulus } \\
(\mathbf{G P a})\end{array}$ \\
\hline $15 \%$ & 61.33 & 21.18 & 2.873 \\
\hline $20 \%$ & 72.15 & 19.79 & 2.121 \\
\hline
\end{tabular}

Compressive stress versus strain curves of an epoxy granite composite with granite to epoxy ratio of 85:15\%wt and 80:20\%wt been presented in Fig.5. The maximum compressive strength was observed for composition with 20:80 \%wt. granite epoxy and the observed value was 72.15 $\mathrm{MPa}$. It was found that increases in the epoxy ratio in the epoxy granite composite increased the compressive strength as shown in Fig.7.

From Fig.7 and Fig.8, it is observed that in specimen with 15\% epoxy the amount of epoxy is little, but it just bonds the particles each other, therefore, the most load carried by granite, at this time the strength decrease while lack of bonding between particles increases brittleness increase and reduced the ductility as the material cannot withstand the load for long times. The epoxy resin in the specimen with $20 \%$ epoxy has a larger amount, therefore it an intersection between particles, therefore, it takes high part of the total load with the granite aggregates, hence the strength increased while brittleness increases and reduced the ductility as the material can withstand the load for long times.

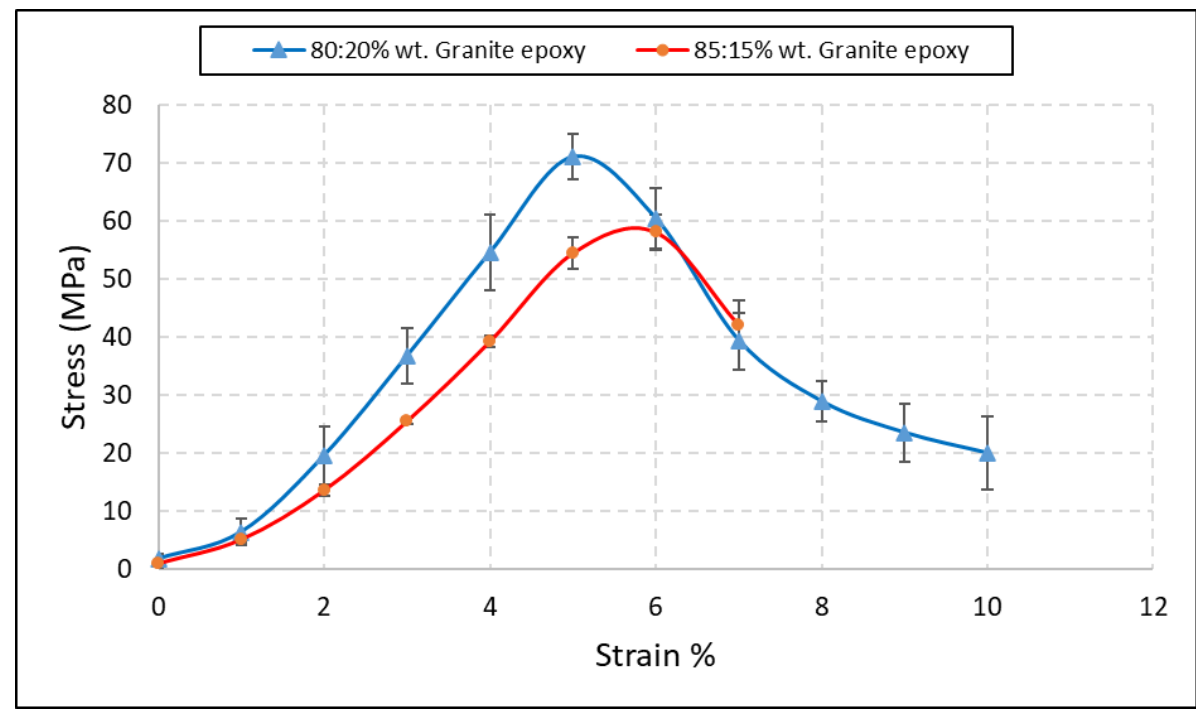

Fig. 7. Epoxy granite Stress-Strain curve. 


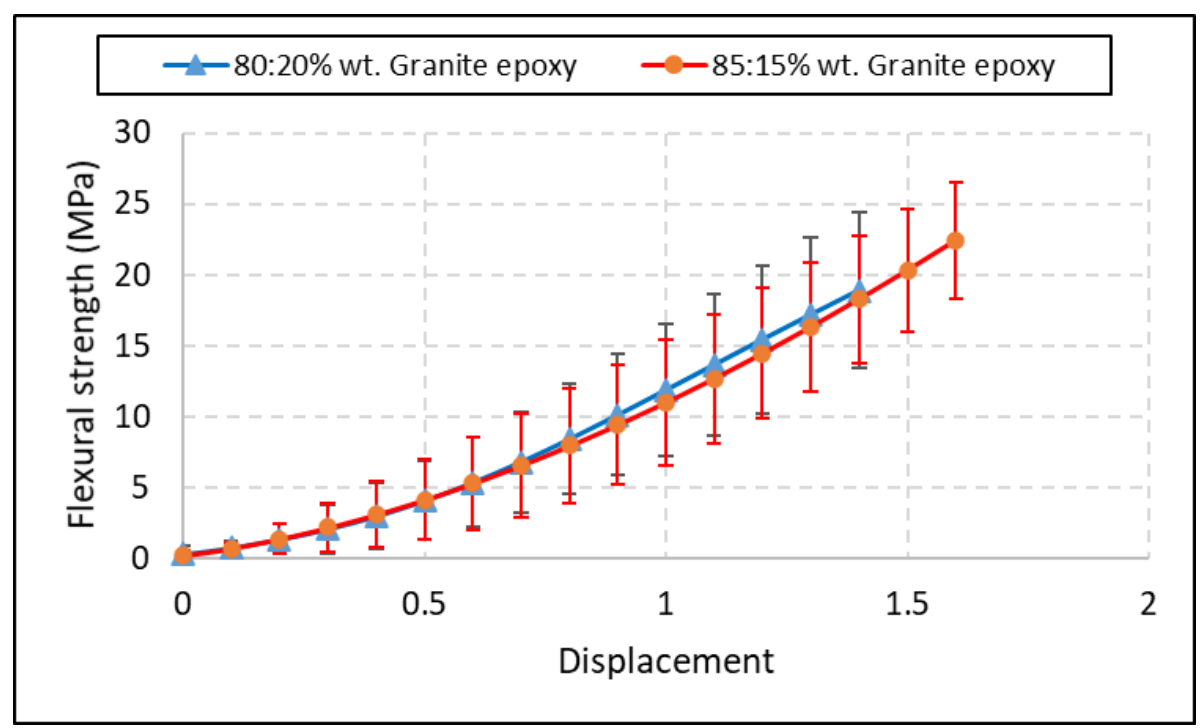

Fig. 8. flexural Stress-Displacement curve at granite to epoxy ratio of $(85: 15) \%$ wt. and (80:20) \%wt.

Samples with $15 \%$ and $20 \%$ in weight of epoxy presented some areas with porosity as shown in Fig.9 and Fig 10. This porosity may be associated with the fabrication process as they have properties rounded format., this porosity may explain the reduction in compressive and flexural strength of samples. An attempt to increase the compressive and flexural strength shall deal with the reduction of porosity, which could be decreased using vacuum chamber. Failure mode in in compression. The failure occurs in the multiple fracture mode, epoxy granite specimen disintegrates along many planes in random directions as shown in Fig.9.

Failure mode in in bending. Brittle fracture modes illustrated in Fig.10. Focus. A dominant crack gradually initiates from the tension face and propagates upward to the load application point. The load-displacement curve of the epoxy granite test exhibits a linearly increasing portion up to the peak followed by a gradual post-failure portion accompanied by a relatively large load point displacement. The upper face of the beam subjected to compression force while the lower face subjected to tension force, fracture occurred in the middle third of the tension face.

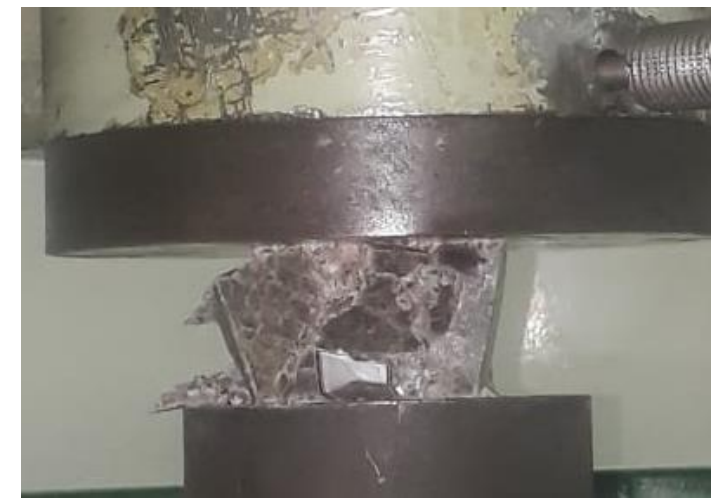

(a)

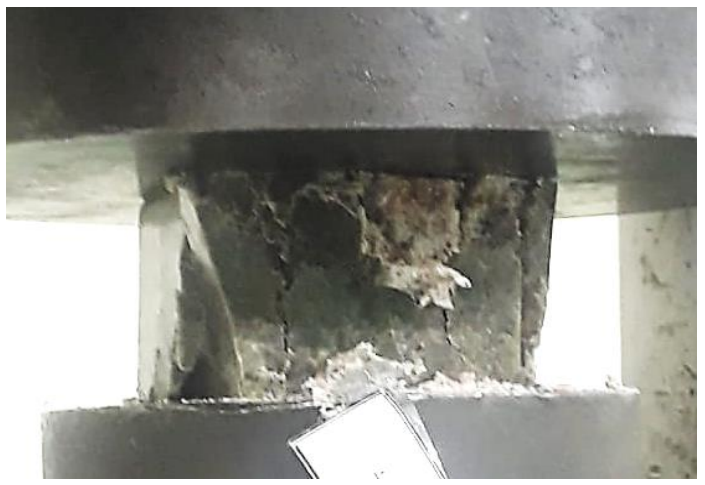

(b)

Fig. 9. Fracture at compressive test, at (a) 20\% wt. epoxy and (b) $15 \%$ wt. epoxy. 


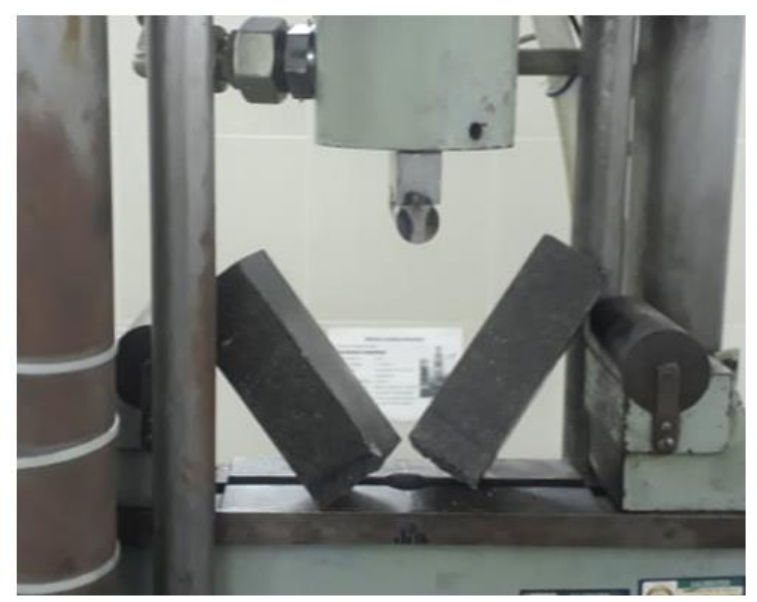

(a)

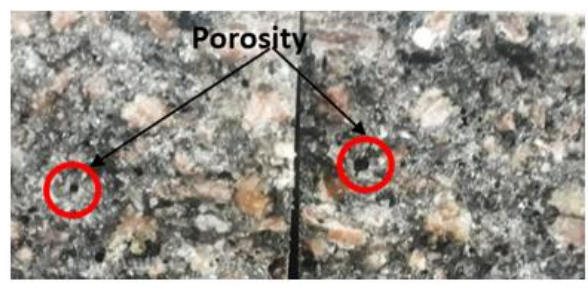

(b)

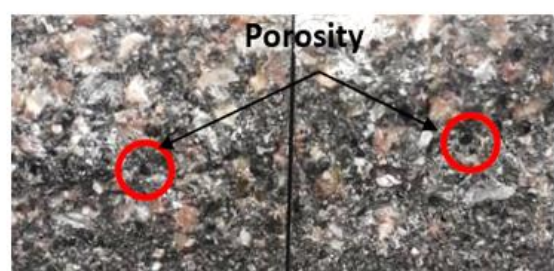

(c)

Fig. 10. (a) Failure under three-point single edge notch bending of particle size, (b) $15 \%$ wt. epoxy and (c) $20 \%$ wt. epoxy.

The variation and the stander error in the values of compressive strength and the flexural strength with the granite to the epoxy ratio of $(85: 15)$ and $(80: 20) \%$ wt are represented graphically as shown in Fig.11. It was observed that the epoxy granite composite mix ratio proved at two different optimum levels, 80:20 for compressive strength and 85:15 for flexural strength. Epoxy granite composite with $20 \%$ in weight epoxy has superior properties to epoxy granite composite with $15 \%$ in weight epoxy.

The variation of the mechanical properties such as compressive and flexural strength of the composite material cement concrete, polyester concrete, and natural granite [25] [26] [15] with the epoxy granite composite is represented graphically as shown in Fig.12. and Fig.13. It was found that cement concrete seems to have inferior strength while both the polyester concrete and epoxy granite composite have considerably superior properties than the cement concrete. Epoxy granite composite has many superior properties than the polyester concrete. The properties of epoxy granite are superior in comparison to natural granite, making it clear that there was a strong interaction between the particles and the matrix and indicating that the low occurrence of pores in epoxy granite provided material with enhanced mechanical properties.

The average density $(\boldsymbol{\rho})$ of the two composites of epoxy granite calculated according to the following formula,

$$
\boldsymbol{\rho}=\frac{\boldsymbol{m}}{\boldsymbol{v}}
$$

Where: $\mathrm{m}$ is the mass of the epoxy granite specimen $(\mathrm{Kg}), \mathrm{v}$ is the volume of the specimens $\left(\mathrm{m}^{3}\right)$. 


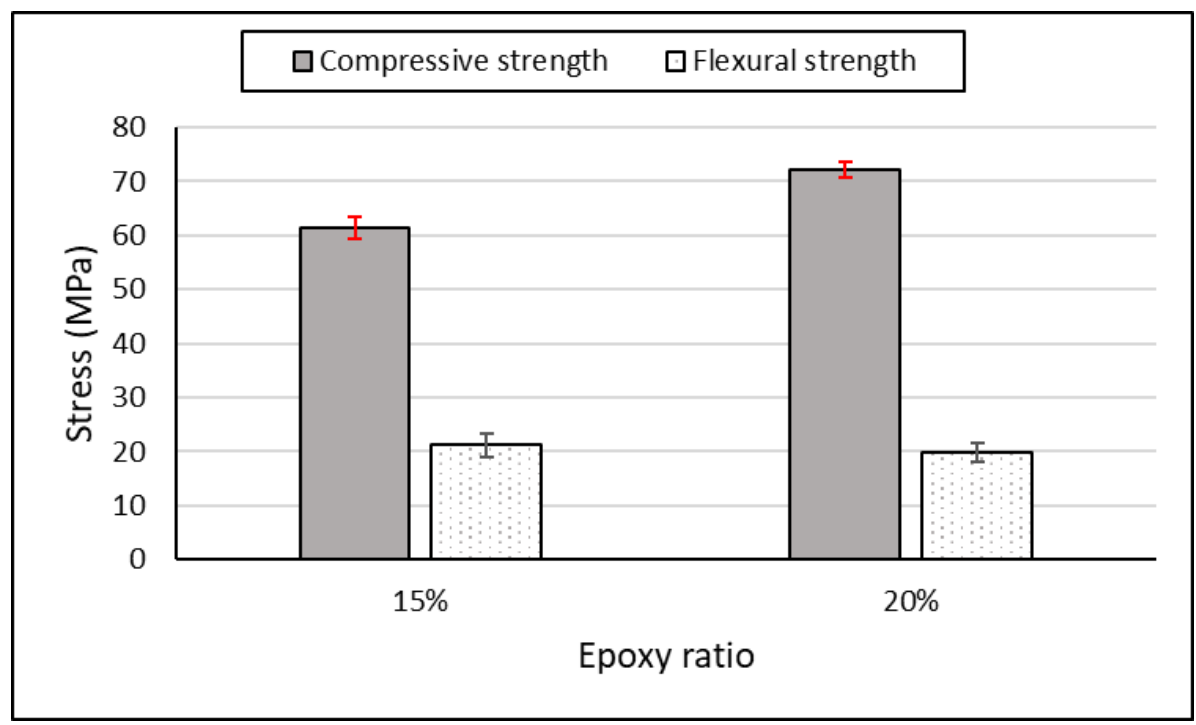

Fig. 11. variation in compressive strength and flexural strength with epoxy granite ratio

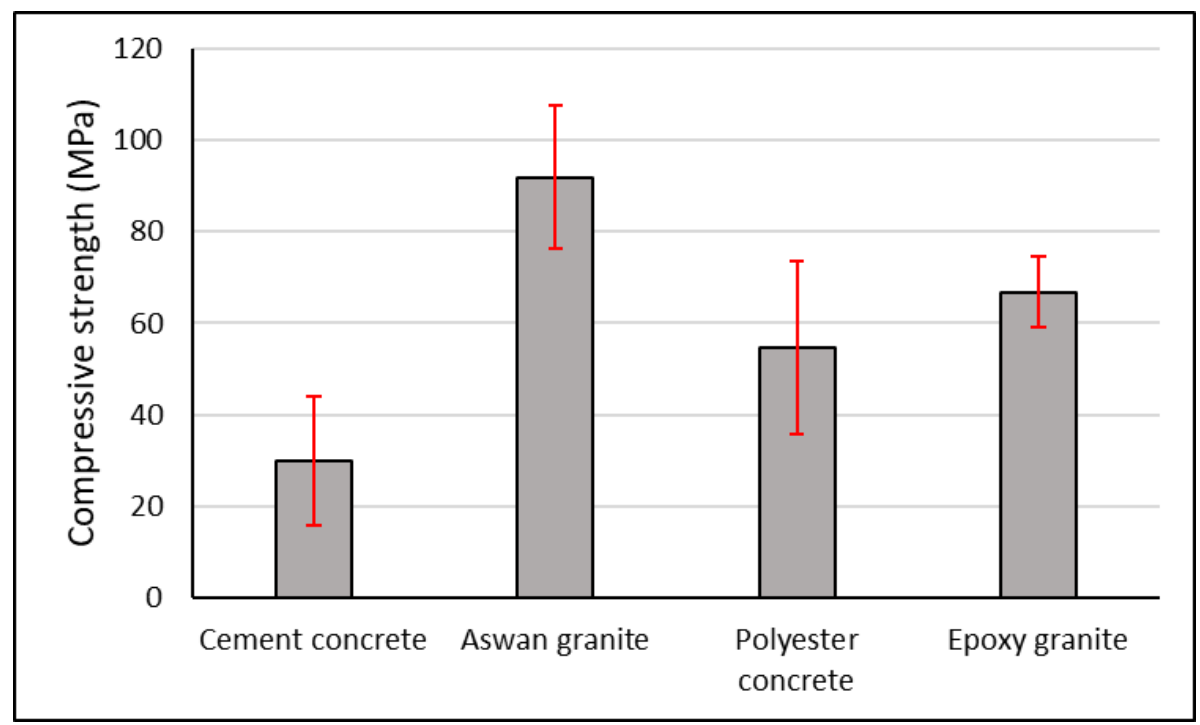

Fig. 12. Variation in compressive strength

The results indicate that the average density of the epoxy granite composite with granite to epoxy ratio of (80:20) \% wt. was less than the density of epoxy granite composite with granite to epoxy ratio of (85:15) \% wt. It observed that density of epoxy granite composite decreases with the increase the epoxy the epoxy percentage. The density of the epoxy granite composite with granite to epoxy ratio of $(85: 15) \%$ wt. was $2079.9 \mathrm{~kg} / \mathrm{m}^{3}$ while it was $1899.9 \mathrm{~kg} / \mathrm{m}^{3}$ for (80:20) \% wt. Epoxy granite composite is less dense than both natural granite and cast iron, the density of the natural granite was $2610 \mathrm{~kg} / \mathrm{m}^{3}$ [14] and the density of cast iron was $7150 \mathrm{~kg} / \mathrm{m}^{3}$ [15] as shown in Fig.14. due to the presence of the polymer material in its composition, which is considered as lighter material. 


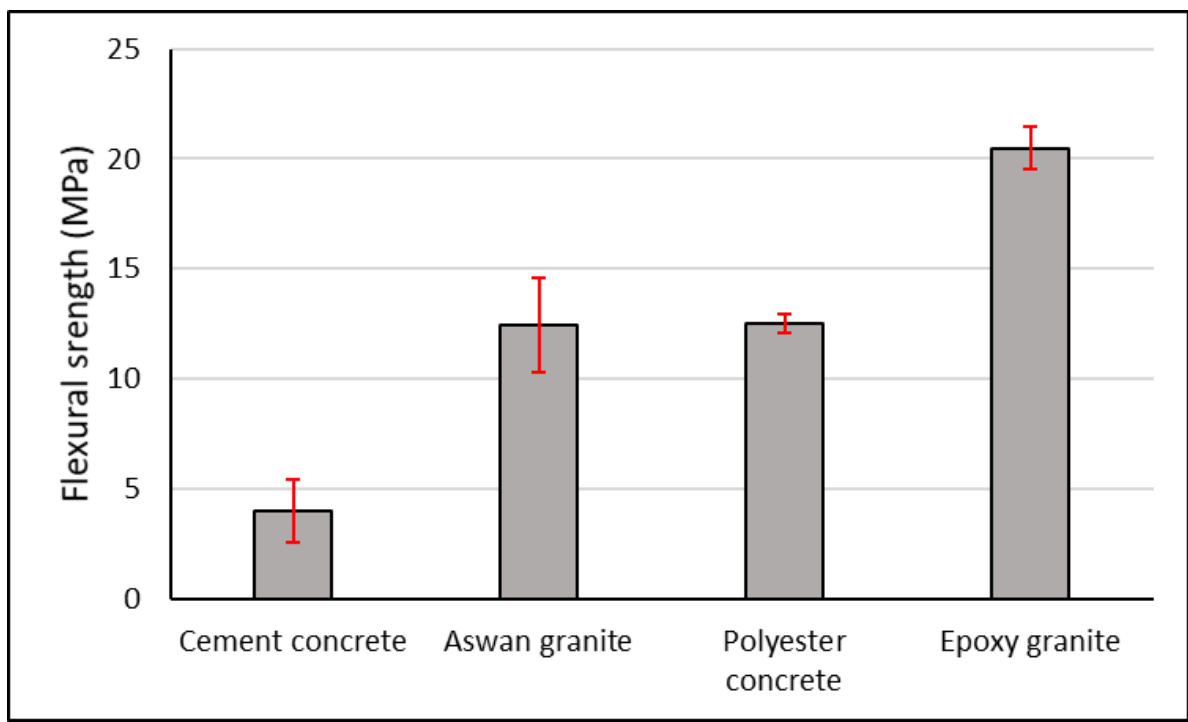

Fig. 13. Variation in flexural strength

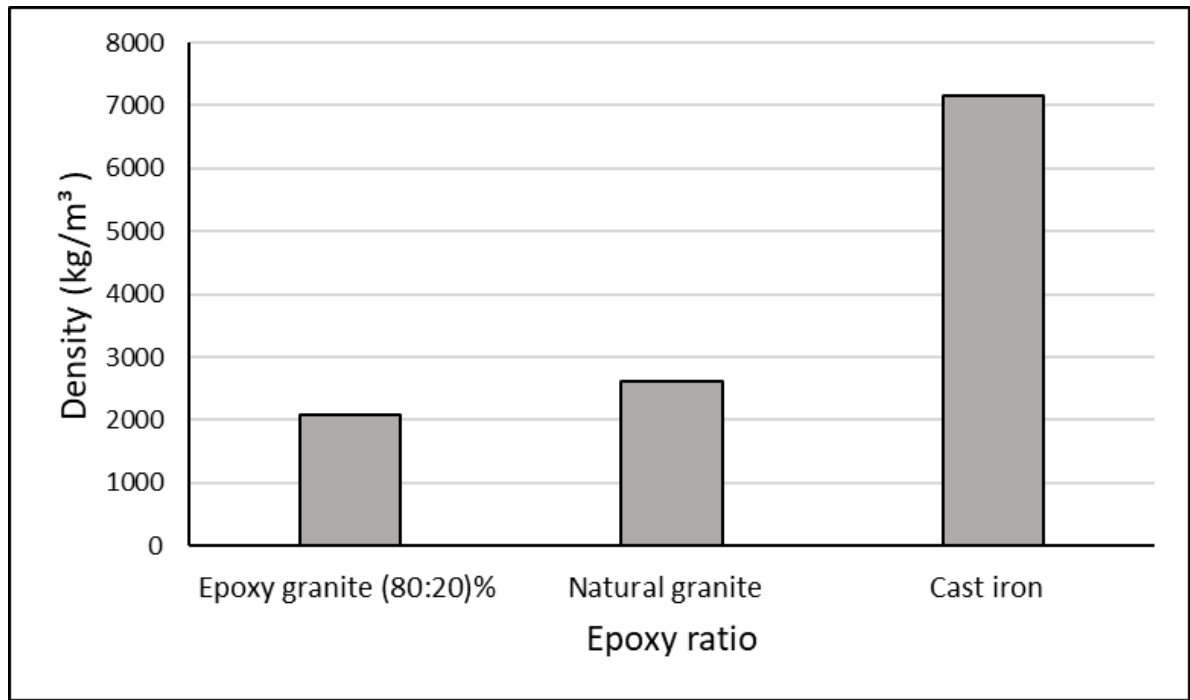

Fig. 14. Variation in density

\section{Conclusions}

Experimental study on mechanical properties of the Egyptian Granite particle filled epoxy resin composite is presented in this study. The influence of epoxy resin content between 15 and $20 \%$ in weight with the granite particles rate of $50 \%$ fine ,25\% Middle and $25 \%$ coarse on compressive and flexural strength of the epoxy granite composite was investigated. The results showed that the compressive strength of epoxy granite composite induced with the highest value at $20 \%$ wt. epoxy ratio. The average values of the compressive strength of the epoxy granite composite were 64.33 and $72.15 \mathrm{MPa}$ for $15 \% \mathrm{wt}$. and $20 \%$ wt. epoxy, respectively. The flexural strength of the epoxy granite induced with the highest value at $15 \%$ wt. epoxy. The value of average flexural strength and flexural young's modulus of epoxy granite composite was $21.18 \mathrm{MPa}$ and $2.873 \mathrm{GPa}$ for $15 \%$ epoxy and was $19.79 \mathrm{MPa}$ and $2.121 \mathrm{GPa}$ for $20 \%$ wt. epoxy. The flexural strength results showed superior magnitude with respect to cement concrete (5 $\mathrm{MPa})$, polyester concrete $(12.2 \mathrm{MPa})$, and natural granite (13.9 MPa). The compressive 
strength results show superior magnitude with respect to cement concrete (40 MPa) and polyester $(68 \mathrm{MPa})$, but it was reduced when compared to natural granite (102.9 MPa). Density of epoxy granite is less than the natural granite and approximately three times lower than cast iron. These results indicate that the epoxy granite composite produced with Egyptian granite residue and local epoxy resin can render the Egyptian granite waste as valuable, potentially profitable materials, Relevance for producing high precision Machine tools and will reduce pollution environmental.

\section{References}

[1] A. A. M. Ahmed, K. H. Abdel kareem, A. M. Altohamy, and S. A. M. Rizk, "Potential Use of Mines and Quarries Solid Waste in Road Construction and as Replacement Soil Undre Foundations," JES. J. Eng. Sci., vol. 42, no. 4, pp. 1094-1105, Jul. 2014, doi: 10.21608/jesaun.2014.115043.

[2] A. Piratelli-Filho and F. Levy-Neto, "Behavior of granite-epoxy composite beams subjected to mechanical vibrations," Mater. Res., vol. 13, no. 4, pp. 497-503, 2010, doi: 10.1590/S151614392010000400012.

[3] S. Orak, "Investigation of vibration damping on polymer concrete with polyester resin," vol. 30, pp. 171-174, 2000.

[4] P. R. Venugopal et al., "Structural investigation of steel-reinforced epoxy granite machine tool column by finite element analysis," Proc. Inst. Mech. Eng. Part L J. Mater. Des. Appl., vol. 233, no. 11, pp. 2267-2279, 2019, doi: 10.1177/1464420719840592.

[5] P. Boral, T. Nieszporek, and R. Gołębski, "The welded CNC machine tool frame," MATEC Web Conf., vol. 157, pp. 1-8, 2018, doi: 10.1051/matecconf/201815701003.

[6] T. C. Chen, Y. J. Chen, M. H. Hung, and J. P. Hung, "Design analysis of machine tool structure with artificial granite material," Adv. Mech. Eng., vol. 8, no. 7, pp. 1-14, 2016, doi: $10.1177 / 1687814016656533$.

[7] P. R. Venugopal et al., "Design and analysis of epoxy granite vertical machining centre base for improved static and dynamic characteristics," Proc. Inst. Mech. Eng. Part L J. Mater. Des. Appl., vol. 234, no. 3, pp. 481-495, 2020, doi: 10.1177/1464420719890892.

[8] R. R. Krishna and S. V. Kumar, "A sian R esearch C onsortium Experimental Studies on Mechanical Properties of Epoxy Granite for Machine Tool Structure using Design of Experiments," vol. 7, no. 3, pp. 1333-1342, 2017.

[9] A. Piratelli-Filho and F. Shimabukuro, "Characterization of Compression Strength of Granite-epoxy Composites Using Design of Experiments," Mater. Res. J. Mater., vol. 11, no. 4, pp. 399-404, 2008, doi: 10.1590/S1516-14392008000400003.

[10] C. Subhash, M. R. Krishna, M. S. Raj, B. H. Sai, and S. R. Rao, "Development of granite powder reinforced epoxy composites," Mater. Today Proc., vol. 5, no. 5, pp. 13010-13014, 2018, doi: 10.1016/j.matpr.2018.02.286.

[11] M. L. P. Gomes, E. A. S. Carvalho, T. J. C. Demartini, E. A. de Carvalho, H. A. Colorado, and C. M. F. Vieira, "Mechanical and physical investigation of an artificial stone produced with granite residue and epoxy resin," J. Compos. Mater., no. 52, 2020, doi: 10.1177/0021998320968137.

[12] P. V Selvakumar, AMohanram, "Analysis of Alternative Composite Material for High," Int. J. Eng., no. 1, pp. 95-98, 2012.

[13] S. S. Balakrishna, H. Girish, G. C. M. Kumar, and S. Narendranath, "Analysis on Mechanical and Dynamic behavior of Granite Epoxy Composites with Cast Iron Particulates as Filler," Indian J. Adv. Chem. Sci., pp. 122-126, 2016. 
[14] D. D. Ubale, A. P. Patil, and K. V Gurav, "EXPERIMENTAL INVESTIGATION OF MATERIAL PROPERTIES OF," pp. 22-24, 2013.

[15] P. Mani, A. K. Gupta, and S. Krishnamoorthy, "Comparative study of epoxy and polyester resinbased polymer concretes," Int. J. Adhes. Adhes., vol. 7, no. 3, pp. 157-163, 1987, doi: 10.1016/0143-7496(87)90071-6.

[16] A. A. M. Ahmed, K. H. Abdel kareem, A. M. Altohamy, and S. A. M. Rizk, "An experimental study on the availability of solid waste of mines and quarries as coarse aggregate in concrete mixes," JES. J. Eng. Sci., vol. 42, no. 3, pp. 876-890, May 2014, doi: 10.21608/jesaun.2014.115024.

[17] A. Rutkauskas, D. Nagrockienè, G. Skripkiūnas, and K. Barkauskas, "Determining Reactivity Level of Granite Aggregate for Concrete," vol. 20, pp. 33-37, 2017, doi: 10.2478/cons-20170005 .

[18] M. Y. Abdellah, A. Abdelhaleem, I. A. Alnaser, and G. T. A. Jaber, "Flexural, compression and fracture properties of epoxy granite as a cost - effective structure materials : new machine element foundation," vol. 8, no. February, pp. 82-98, 2021, doi: 10.3934/matersci.2021006.

[19] H. Mechanical, C. Resistance, and T. E. Coating, "Protective Coating Products Epoxy Paints Kemapoxy 150 Epoxy Paints Great Products," no. 202, pp. 15-16.

[20] O. M. Yousri, M. H. Abdellatif, and G. Bassioni, "Effect of Al 203 Nanoparticles on the Mechanical and Physical Properties of Epoxy Composite," Arab. J. Sci. Eng., vol. 43, no. 3, pp. 1511-1517, Mar. 2018, doi: 10.1007/s13369-017-2955-7.

[21] F. L. Jin, X. Li, and S. J. Park, "Synthesis and application of epoxy resins: A review," Journal of Industrial and Engineering Chemistry, vol. 29. Korean Society of Industrial Engineering Chemistry, pp. 1-11, Sep. 25, 2015, doi: 10.1016/j.jiec.2015.03.026.

[22] R. Liu and X. Wang, "Synthesis, characterization, thermal properties and flame retardancy of a novel nonflammable phosphazene-based epoxy resin," Polym. Degrad. Stab., vol. 94, no. 4, pp. 617-624, Apr. 2009, doi: 10.1016/j.polymdegradstab.2009.01.008.

[23] S. T. Methods, "Standard Test Methods for Compressive Strength of Molded Soil-Cement Cylinders 1," Transp. Res., vol. 84, no. July 1996, pp. 1-6, 2000.

[24] S. T. Method, "Standard Test Method for Flexural Strength and Modulus of Elasticity of Chemical- Resistant Mortars , Grouts, Monolithic Surfacings , and," Annu. B. ASTM Stand., vol. 02, no. Reapproved 2008, pp. 1-5, 2011.

[25] N. Mahendrakumar, S. Syathabuthakeer, and P. V Mohanram, "Study of Alternative Structural Materials for Machine Tools 1*1*," no. Aimtdr, pp. 1-6, 2014.

[26] G. M. A. Wahab, M. Gouda, and G. Ibrahim, "Study of physical and mechanical properties for some of Eastern Desert dimension marble and granite utilized in building decoration," Ain Shams Eng. J., vol. 10, no. 4, pp. 907-915, 2019, doi: 10.1016/j.asej.2019.07.003. 


\section{دراسة عملية على مقاومة الانضغاط وجساءة الانجناء للمادة المركبة من الايبوكسي جرانيت للتطبيقات الصناعية الإناع}

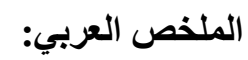

في مصر، يتم إنتاج كميات كبيرة من نفايات الجرانيت سنويًا أثناء عمليات استخر اج صخور الجرانيت. تمثل هذه النفايات مصدرًا مفيدًا محتملً للمو اد لمجمو عة متنو عة من التطبيقات مثل مادة الحثو في المادة المركب من الجر انيت الإيبوكسي. في هذا العمل، تمت در اسة مادة مركبة جديدة كبديل عن المو اد التقليدية المستخدمة في اجز اء الماكينات، مثل الحديد الزهر، لإنتاج كفاءة أفضل بتكلفة أقل. المادة المركبة الجديدة مبنية على الجر انيت، وهو مادة طبيعية تتمتع بقوة ضغط استثنائية وخصائص التخميد مما يجعلها مثالية لهيكل الأدو ات الآلية. تم إجر اء در اسة تجريبية على مركب مصفوفة بوليمر، تم تطويره باستخدام جسيم جر انيت كمادة مقو اة مرتبطة بمصفوفة بوليمر إيبوكسي. تهدف هذه الدراسة إلى التعرف على الخو اص الميكانيكية لمركب الإيبوكسي الجرانيت باستخدام الإيبوكسي المحلي (150 kemapoxy) ومخلفات الجر انيت في المحاجر المصرية و إعادة استخدام مخلفات الجر انيت لإنتاج مركب الإيبوكسي الجرانيت ذي الطبيعة الصديقة للبيئة. كان متغير المعالجة الذي تم فحصه هو نسبه الإيبوكسي المتو اجده في تكوين مركب الاييوكسي جر انيت، وتم إجر اء التوصيف الميكانيكي عن طريث اختبار ات الانضغاط و الانحناء وفقًا لمعيار ASTM باستخدام آلة الاختبار الثاملة. تم شراء جرانيت أسوان الأحمر المتوفر تجاريا وسحقه ونخله إلى ثثلاثة أحجام تتر اوح من • 1 1 . • إلى 1 مم على التوالي. تم استخدام نسب إيبوكسي • ب...1، 10:10 مع مزيج من الأحجام التر اكمية من الجر انيت بنسب صغيرة ومتوسطة وخشنة من

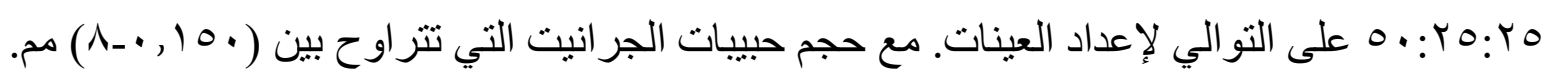

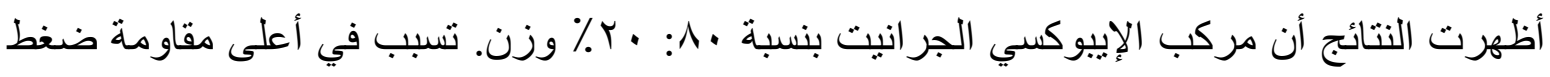

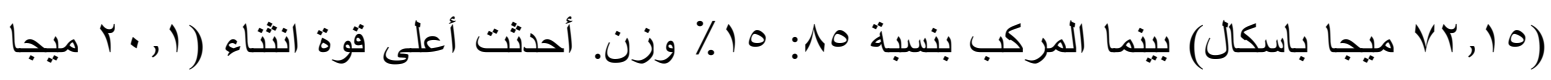
باسكال). يُظهر مركب الجرانيت الإيبوكسي نتائج متفوقة فيما بتعلق بالخرسانة الأسمنتية وخرسانة البوليستر و الجر انيت الطبيعي. تشير نتائجنا إلى أن مركب الجر انيت الإيبوكسي بنسبة • ^: • ب٪ بالوزن. مع الخصائص الميكانيكية الجيدة قد يكون لها إمكانات عالية في تطبيق أساس الماكينة كمو اد غير مكلفة. 